\title{
Tilting at windmills: health reform and the 2004 US presidential election
}

$\mathrm{H}$ ealth reform is once again a front-page story in the United States. This is hardly a surprise: since 1970, US health policy has followed a predictable (and seemingly unending) cycle of discovering a crisis in the health system, identifying and debating policy solutions, ultimately doing little or nothing in the way of reform while extolling the virtues of markets and state innovation, only to rediscover later that the system is still in crisis. Having rejected the health reforms proposed by President Bill Clinton in 1993, which would have created a system of universal health insurance through and employer mandate, and having largely ignored the issue for the ensuing decade, the US finds itself (again) with a troubled health system badly in need of reform. ${ }^{1}$

In recent years, the number of Americans without health insurance has grown substantially while health care spending has accelerated (see Box 1). The growth in the uninsured population is the result of a significant decline in employer-sponsored insurance, the primary source of health insurance for US workers and their families. The 2001 recession and weaker-than-expected job growth in subsequent years has led to the erosion of health insurance coverage, especially among small businesses.

Another factor driving the growth in the uninsured population is rising health care costs. The rate of increase for health premiums "slowed" in 2004 to $11 \%$, and it is a sign of the depressing state of affairs in US $\circ$ health policy that this was actually considered good news. Private-sector actors in the health care system are pessimistic about the ability of managed care, competition, or any other market-led strategy to stem this tide, although there is develop- ing interest in insurance plans that require more cost-sharing from patients, including high deductibles. (These misnamed "consumer-driven health care" plans are the latest magic bullet in US health policy). ${ }^{6}$ At the same time, cash-strapped states have curtailed efforts at expanding publicly funded insurance coverage and some have cut enrolment and benefits in health programs for the poor. Meanwhile, premiums for US Medicare, which provides federal health insurance to over 41 million elderly and disabled people, are slated to rise by $17 \%$ next year.

The 2004 US presidential election, then, is taking place against the backdrop of a steady stream of bad news about the health care system. Yet there is no consensus over what, if anything, should be done about these problems. Indeed, presidential candidates George $W$. Bush and John Kerry have offered dramatically different proposals for health reform (see Box 2).

While the political differences between the 2 candidates on health policy may be apparent, political calculations also underlie the Kerry and the Bush reform plans. The Bush strategists calculate that, with public attention focused on Iraq and the war on terror, they do not need to offer a comprehensive health reform alternative. They believe that the Democrats' advantage on the issue can be neutralized by criticizing the Kerry plan as "government-run health care" and by emphasizing its unaffordability (in the context of record federal budget deficits) and reliance on tax increases. The Kerry campaign, applying lessons learned from the Clinton health-reform debacle, is betting that a plan that does not alter health insurance arrangements for already insured Amer- icans or impose any mandates on employers, and that builds on familiar public programs as well as private insurance, can be sold to the voting public. Through a reinsurance policy that would keep the costs of employer-based plans down by relieving them of $75 \%$ of the burden of the most expensive patients, the Kerry plan is designed, in part, to give insured voters a stake in health reform and thereby broaden the constituency for change beyond the predominantly low-income (and low-voting) uninsured population. The Kerry plan is also predicated on the belief that voters will support progressive financing of health reform, since the insurance expansion is to be paid for by rolling back tax cuts for the wealthiest Americans (those with annual earnings over \$200 000).

There is one calculation that both plans apparently share: cost control is a political nonstarter. Neither candidate would do anything to control rising health care spending. (The Kerry reinsurance proposal could, if it worked, mitigate premium increases in pri-

Box 1: US health care: trends in insurance and in spending

- Number of Americans without health insurance in 2003: 45 million (15.6\% of population)

- Increase in uninsured population since 2002: 4 million $^{2}$

- Percentage of population under age 65 with employer-sponsored insurance in 2001: 67\%

- Percentage in 2003: 63\% ${ }^{3}$

- Average yearly growth in health care spending, per capita, 2001-2003: 9\%

- Increase in premiums for employer-sponsored health plans since 2001: 59\%

- Increase in wages in the same period: $12 \%$

- Scheduled increase in premiums for Medicare recipients in 2005: 17\% 


\section{ANALYSIS}

\section{Box 2: The US presidential election platforms on health insurance ${ }^{7}$}

\section{George Bush (Republican)}

- Tax credits for uninsured to purchase non-group insurance. (Maximum credit $\$ 3000$ for families, $\$ 1000$ for individuals with low incomes)

- Health savings accounts to enable individuals to contribute tax-preferred funds to pay for medical expenses (in combination with a high-deductible insurance policy)

- Association Health Plans that allow small businesses to pool together to buy health insurance

\section{Projected coverage and costs}

- Would cover 4 million currently uninsured

- $\$ 70$ billion over 10 years costs put reform on the agenda, but the better a plan actually is at controlling costs, the worse its political viability, consequently generating reform proposals that only pretend to restrain spending. ${ }^{8}$ The debate over reimportation of prescription drugs from Canada is the exception that proves the rule that the US is not serious about cost control. Yet, as has been discussed in these pages, ${ }^{9}$ even this debate is quixotic.

The immediate future of health reform in the US depends as much on the results from this year's congressional elections as it does on the presidential contest. The probability and shape of health reform will turn crucially on the partisan configuration of Congress in 2005 , as well as on trends in costs, insurance and employment. However, those hoping that the US will at last achieve universal coverage and control costs are likely be disappointed by both parties' proposals and by whatever incremental action (or inaction) that follows this election.

\section{Jonathan Oberlander}

Associate Professor of Social

Medicine

University of North Carolina-Chapel Hill

Visiting Scholar

Princeton University Center

for Health and Wellbeing

Princeton, NJ

Dr. Oberlander's work is supported by the Greenwall Foundation Faculty Scholars Program in Bioethics.

\section{References}

1. Oberlander J. The US health care system: on a road to nowhere? $C M A \mathcal{F}$ 2002;167(2):163-7.

2. US Census Bureau. Income, poverty and health insurance coverage in the united states: 2003. Available: www.census .gov/hhes/www/hlthin03.html (accessed 2004 Sept 28).

3. Strunk BC, Reschovsky JD. Trends in US health insurance coverage, 20012003. Washington: Center for Studying Health System; 2004. Tracking Report 9. Available: www.hschange .com/CONTENT/694/ (accessed 2004 Sept 28).

4. Strunk BC, Ginsburg PB. Tracking health care costs: trends turn downward in 2003. Washington: Center for Studying Health System; 2004. Data Bulletin 27. Available: www.hschange .comCONTENT/679/ (accessed 2004 Sept 28).

5. Kaiser Family Foundation, Health Research and Educational Trust. Employer health benefits 2004 survey. Menlo Park(CA): Kaiser Family Foundation; 2004. Available: www.kff .org/insurance/7148/index.cfm (accessed 2004 Sept 28).

6. Nichols LM, Ginsburg PB, Berenson RA, Christianson J, Hurley RE. Are market forces strong enough to deliver efficient health care systems? Confidence is waning. Health Aff (Millwood) 2004;23: 8-21.

7. Collins SR, Davis K, Lambrew JM. Health care reform returns to the national agenda: the 2004 presidential candidates' proposals. New York: Commonwealth Fund; 2004. Available: www.cmwf.org/usr_doc/collins _reformagenda_671.pdf (accessed 2004 Sept 28).

8. Oberlander J. The politics of health reform: why do bad things happen to good plans? Health Aff (Millwood) 2003; W3 (web exclusive);391-404. Available: http://content.healthaffairs .org/cgi/content/abstract/hlthaff.w3.391 v1 (accessed 2004 Sept 28).

- Would cover 27 million currently uninsured

- $\$ 900$ billion over 10 years 